\title{
Review
}

\section{Sporadic endocrine tumours and their relationship to the hereditary endocrine neoplasia syndromes}

\author{
J. W. Koper and S. W. J. Lamberts
}

See paper on page 487 .

\begin{abstract}
In the last years of the previous century the genes involved in the aetiology of five endocrine tumour syndromes have been identified. The tumour-suppressor gene that is responsible for Von Hippel-Lindau Disease was cloned in 1993; multiple endocrine neoplasia (MEN) types $2 \mathrm{~A}$ and $2 \mathrm{~B}$ and familial medullary thyroid carcinoma were found to be caused by activating mutations in the ret proto-oncogene in 1993 and 1994, and most recently the menin-gene, another tumour-suppressor gene, was shown to be associated with MEN-1. As usual, the answer to one question leads to innumerable new questions. And so, now we want to know the extent to which germ-line mutations (de novo, or otherwise previously undetected) in these genes play a role in the occurrence of the various endocrine tumours that are associated with these syndromes in apparently sporadic cases. We also want to know if the nature of the (germ-line) mutation conveys any information about the characteristics (phenotype) of the disease. We want to know the role of somatic mutations in these genes in truly sporadic tumours. And finally we want to know the exact function of the proteins that are encoded by these genes. The paper by Roijers et al. [1] elsewhere in this issue is an example of a small but well-directed step on the way to address some of these questions with respect to the meningene. It addresses the problem of patient selection when looking for germ-line mutations in apparently sporadic MEN-1 patients. In this review we want to give a brief summary of the present status with regard to some of the questions mentioned above, in relation to the endocrine tumour syndromes caused by the $v h l$, ret and menin genes.
\end{abstract}

Eur $\mathcal{F}$ Clin Invest 2000; 30 (6): 493-500

\section{Introduction}

Between 1993 and 1997 the genes involved in a number of hereditary endocrine tumour syndromes have been identified. Von Hippel-Lindau Disease (VHL) was shown in 1993 to be caused by inactivating mutations in the vhl tumour-suppressor gene (gene map locus 3p26-p25) [2]. Also in that year, a specific set of activating mutations in the ret proto-oncogene (10q11.2) were found in most families with the multiple endocrine neoplasia type $2 \mathrm{~A}$ syndrome (MEN-2A) [3]. In the same year the same mutations were

Department of Internal Medicine, Erasmus University Rotterdam, School of Medicine, Rotterdam, the Netherlands (J. W. Koper, S. W. J. Lamberts).

Correspondence to: Jan W. Koper, Department of Internal Medicine, room Bd 277, Dijkzigt University Hospital, P.O.B. 2040, NL 3000 CA Rotterdam, the Netherlands.

E-mail: koper@inw3.fgg.eur.nl

Received 25 January 2000; accepted 20 February 2000 shown to be the cause also of familial medullary thyroid carcinoma (FMTC) [4]. A year later, in 1994 the ret protooncogene was also implicated in MEN-2B [5,6], albeit that a different activating mutation in a different region of the gene was involved here. Finally, in 1997, the menin tumoursuppressor gene (11q13) [7,8] was identified as the affected gene in MEN-1 families.

The identification of these genes has led to a considerable amount of research trying to elucidate the role of these genes and the way in which their activation (ret) or inactivation (vhl, menin) leads to cancer in specific organs. There has also been much interest in the question whether these genes are also involved - through somatic mutations - in the sporadic analogues of the tumours that occur in these five syndromes. Last, but not least, there is the question of case finding. In all these genes new germ-line mutations can occur, thus creating new families at risk. In various papers the frequency of de novo germ-line mutations in these genes in patients with apparently sporadic endocrine tumours is estimated to be somewhere between 3 and $7 \%$ of the cases [9-11]. The question is how to proceed in 
order to identify these new cases of hereditary disease among the vast majority of sporadic cases. In a paper in this issue Roijers et al. [1] describe their efforts to narrow down the field, in their search for new cases of MEN-1.

\section{Von Hippel-Lindau disease}

VHL (MIM 193300) is characterized by the familial occurrence of tumours in a large number of organs and organ systems. The most important of these are clear cell renal tumours, pheochromocytomas, retinal angiomas and cerebellar and spinal haemangioblastomas. Since the identification of the $v h l$-gene [2], 200 different mutations have been identified in affected families (and recorded in The Human Gene Mutation Database http://http://www.uwcm. ac.uk/uwcm/mg/hgmd0.html [12]). These mutations can roughly be divided into two classes: first, mutations resulting in a truncated, inactive or absent protein, arising from the occurrence of premature termination codons through a variety of mechanisms (nonsense mutations, insertions and deletions associated with frameshifts, and gross deletions); and second, missense mutations. The first class is predominantly associated with clear-cell renal carcinoma, retinal angioma and cerebellar and spinal haemangioblastoma, while in the second class these tumours also occur, but are now often accompanied by phaeochromocytomas $[13,14]$. In addition to these two classes, vhl-alleles are found, which result in the occurrence of phaeochromocytomas alone [15]. Further indications that there exists a strong genotype-phenotype relationship for $v h l$-alleles is found in the observation that identical mutations in Caucasian and Japanese VHL-families produce similar cancer phenotypes [15]. Somatic mutations in the vhl-gene have been found in 10 out of 20 capillary haemangioblastomas of the central nervous system [16]. In two of these 10 patients the same mutations were also found in lymphocyte DNA, indicating that these two patients carried (new?) germ-line mutations in the $v h l$-gene. In a number of recent studies [17-19], somatic mutations were identified in more than $50 \%$ of the sporadic (non-papillary) renal cell carcinomas. From one of these studies it also appeared that these mutations were predominantly of the same class (protein-truncating mutations) as those that confer type 1 VHL in the case of germ-line mutations [18]. From a literature study these authors also conclude that in the case of VHL such mutations not only reduce the chance of the occurrence of a phaeochromocytoma, but also increase the chance of renal cell carcinoma. On the basis of clinical observations Neumann et al. [20] suggested that apparently sporadic pheochromocytomas are frequently part of VHL (19\%) or MEN-2 (4\%). More recent studies [10,21-23] have shown that only in $5-10 \%$ of the patients presenting with phaeochromocytoma germ-line mutations in the vhlgene could be detected. The discrepancy may be solved by the observation that in the group of people studied initially [20] a founder-effect was later (after the $v h l$-gene had been cloned) identified [24].
The VHL-protein is widely expressed $[2,25]$ and exists in two forms of 213 and 160 amino acids, respectively, the second form originating from an internal translation initiation site $[26,27]$. Its function has not yet been elucidated completely, but is associated with the regulation of transcription elongation by RNA polymerase II [28]. Transcription elongation is stimulated by the multimeric protein complex elongin [29,30], and the intact VHL-protein can inhibit elongin activity by sequestering the $\mathrm{B}$ and $\mathrm{C}$ subunits of the elongin complex. More specifically the VHLprotein appears to be involved in the down-regulation of the expression of vascular endothelial growth factor $[31,32]$, an observation that corresponds well with the highly vascularized nature of most VHL-associated tumours. Interestingly mutations in one of the few 'hotspots' for $v h l$-mutations, codon 167 [15], were found to coincide with the loss of elongin-binding capacity by the VHL-protein [28].

\section{Multiple endocrine neoplasia type I}

MEN-1 (MIM 131100) is a dominantly inherited endocrine cancer syndrome, characterized by the occurrence of parathyroid adenomas, pituitary adenomas, adrenocortical adenomas, tumours of the endocrine pancreas, duodenal gastrinomas and carcinoid tumours. In 1997 the gene responsible for MEN-1, the menin-gene, localized on chromosome 11q13, was cloned $[7,8]$. The gene is organized in 10 exons and codes for a widely expressed 610 amino acid protein (menin) that bears no resemblance to other known proteins, making predictions about its function more difficult. Menin has been shown to be a nuclear protein [33], and it is probably involved in the regulation of transcription via interactions with the transcription factor JunD [34]. The tumour-suppressor nature of the menin-gene has since then been confirmed by mutational analysis in MEN-1 families, revealing more than 100 different inactivating mutations (e.g [35-37] and the Human Gene Mutation Database [12]). Interestingly, there seem to be a number of hotspots for deleterious mutations in the gene. These sites appear to be located at positions where the nucleotide sequence is prone to undergo replication errors, e.g. due to slipped-strand mispairing $[37,38]$ rather than at positions coding for amino acids essential for the function of the protein. Furthermore, a wide variety of missense and nonsense mutations, evenly distributed all over the gene has been identified. While the original descriptions of the MEN-1 syndrome placed much emphasis on the intrafamilial homogeneity of the phenotype, it has now become clear that such a genotype-phenotype relationship is rare in the case of MEN-1 [36,37,39]. However, irrespective of the phenotype, the MEN-1 syndrome appears to be highly penetrant. On the basis of a large group of patients, Basset et al. calculated an age-related penetrance of $98 \%$ by 40 years of age, increasing to $100 \%$ by 60 years of age $[36,40]$, but lower percentages have also been found [41]: $50 \%$ penetrance at 50 years of age. Studies in a large kindred 
[42] suggest that the phenotype - as represented by the type of tumours occurring, the age of onset and the penetrance - is more dependent upon the genetic environment than upon the nature of the menin mutation. This is illustrated by the observation that the phenotype in different branches of one large family showed considerable differences [42]. Somatic mutations in the menin-gene have been found in $20-30 \%$ of the sporadic parathyroid tumours [43] but not in familial hyperparathyroidism [35]. In sporadic insulinomas/gastrinomas $[44,45]$ and in sporadic lung carcinoids [46] a considerable number of the tumours also show somatic mutations in the menin-gene. Despite extensive screening of large numbers of tumours, no mutations in the menin-gene have been found in sporadic pituitary tumours [47], nor in sporadic adrenal neoplasms [48-50].

\section{Multiple endocrine neoplasia type 2A and 2B and familial medullary thyroid carcinoma}

MEN-2A (MIM 171400), MEN-2B (MIM 162300) and FMTC (MIM 155240) form a typical example of clinically different syndromes, all caused by mutations in the same gene. The three syndromes are dominantly inherited and their common denominator is the occurrence of medullary thyroid carcinoma, alone in the case of FMTC, or accompanied by phaeochromocytomas and parathyroid hyperplasia (MEN-2A), or phaeochromocytomas, mucosal neuromas and developmental abnormalities (MEN-2B). The retgene was identified as a proto-oncogene in 1985 [51] by finding it rearranged in an NIH3T3 transfection assay, hence its name: REarranged during Transfection. Interestingly, before its involvement in MEN-2 became apparent, it had already been shown that the ret-gene played a role in (sporadic) papillary thyroid carcinoma [52]. In contrast to the menin- and vhl-tumour suppressor genes, the ret-gene is a proto-oncogene. The activating mutations that have been identified in this gene in MEN-2 and FMTC are of two types. In approximately $96 \%$ of the MEN-2A and FMTC families, any one of five cysteine residues $(609,611,618$, 620 or 634) was found to be mutated [3,4,53-56] (Fig. 1). In $95 \%$ of the MEN-2B families a methionine to threonine mutation was identified in codon 918 [5,6,53] (Fig. 1). The effects of the ret-mutations in MEN-2A, MEN-2B and FMTC are closely related to the function of the RETprotein. RET is a receptor protein with tyrosine-kinase activity. Together with the co-receptor, glial-cell-derived neurotrophic factor receptor- $\alpha,(\mathrm{GDNF}-\mathrm{R} \alpha)$, it takes care of the intracellular transmission of the GDNF signal [57-59]. The signalling cascade involves binding of GDNF to the GDNF-R $\alpha$, two copies of liganded GDNF-R $\alpha$ then recruit two copies of RET, which upon dimerization autophosphorylate and thus initiate the intracellular signalling chain [57-59]. The abrogation of one of the extracellular cysteine residues that occurs in MEN-2A and FMTC, possibly results in ligand-independent auto-dimerization of the RET-protein with constitutive activation as the oncogenic consequence [60-63]. Genotype-phenotype relationships exist in $\mathrm{MEN}-2 \mathrm{~A}$, although they are not absolute. In a very large study, comprising $477 \mathrm{MEN}-2$ and FMTC families [53], mutations in codon 634 were found to be strongly associated with the occurrence of medullary thyroid carcinoma in combination with phaeochromocytoma. On the other hand the presence of mutations in one of the other codons showed a strong correlation with the combination of medullary thyroid carcinoma and HPT [53].

In MEN-2B the replacement of methionine 918 of the RET-protein by a threonine residue, located within the tyrosine kinase domain of the protein, has been shown to affect the substrate specificity of the kinase activity $[62,64]$. While tyrosine kinases with methionine residues at a similar position in the active site typically phosphorylate tyrosine residues of membrane-bound substrates, threonine residues at this position lead to specificity for soluble (protein) substrates such as src and $a b l[64]$.

\section{Searching mutations}

In the previous sections we have tried to give an overview of the genetic causes of the MEN syndromes and VHL disease. Here we want to consider some of the aspects that come to mind when the question is asked if it makes sense to look for mutations in the genes involved in these tumour syndromes in patients. In this respect we would like to distinguish three groups: first, members, known or not known to be affected, of MEN and VHL families; second, patients, not known to be members of such families, presenting with (apparently) sporadic tumours associated with these syndromes; and third, somatic mutations in the sporadic analogues of tumours that are also associated with these syndromes.

Many of the issues discussed here have been addressed in two papers in a recent issue of Science by Fearon [65] and Ponder [9].

\section{Families}

With the identification of the responsible genes, specific mutations causing the disease have been found in many MEN and VHL families. Without wanting to underestimate the psychological and ethical factors involved [9], we feel that both the potential patients and their families and society benefit from the identification of family members who are carriers of these mutations. A 'poll' held at a recent meeting on MEN and VHL suggests that the majority of clinicians share this opinion [66]. With regard to the MEN2A syndrome, a striking example of the benefits of such mutational screening, as compared to clinical and biochemical screening, was presented by Lips et al. [67]. The paper illustrates that the clinical and biochemical screening for MEN-2 result in false positives (and unnecessary 

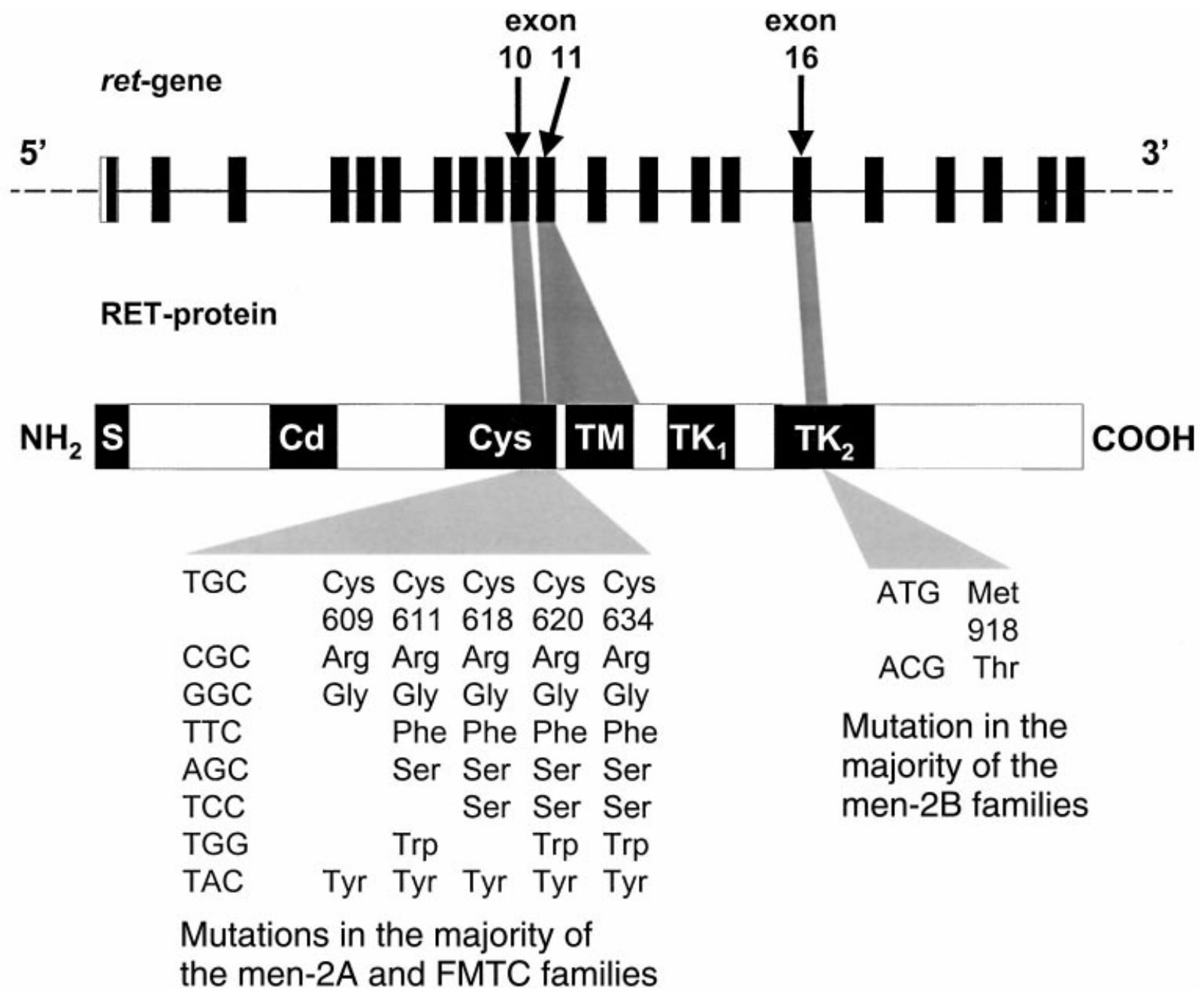

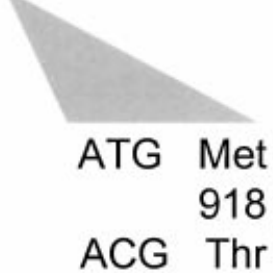

Mutation in the majority of the men-2B families
Figure 1 The organization of the ret-gene, mRNA, and protein, and the position of the amino acid residues mutated in multiple endocrine neoplasia type $2 \mathrm{~A}(\mathrm{MEN}-2 \mathrm{~A})$, familial medullary

thyroidectomies) but also in an alarming number of false negatives and increased risk for the patients. Moreover, when the specific mutation associated with the disease has been identified in a family, screening family members 'at risk' is relatively easy because the target is known, and simple techniques, such as restriction fragment length polymorphism analysis, allele specific hybridization, or single strand conformation polymorphism (SSCP) can be used. This type of screening should be carried out at an age lower than the lowest age reported for the first occurrence of the first manifestations of these tumour syndromes [66]. In this respect, the age of 10 years is usually mentioned. However, in MEN-2 and FMTC some authors suggest that thyroidectomy should be performed as early as at the age of 5 years [68], especially in the case of MEN-2B where medullary thyroid carcinoma is known to have an earlier age of onset and a more aggressive nature. Parenthetically, this observation is widely mentioned with regard to MEN$2 \mathrm{~B}$, but we could find no specific reference to it in the thyroid carcinoma (FMTC) and MEN-2B. S, signal peptide; $\mathrm{Cd}$, cadherin-like domain; Cys, cysteine-rich domain; TM, trans-membrane domain; TK, tyrosine-kinase domain.

literature. The advantages of such screening are obvious: in the case of MEN-2 and FMTC prophylactic thyroidectomy will prevent metastatic disease, and thus eliminate the most important source of disease in the patients. For all other manifestations of MEN-2 well-directed clinical surveillance may prevent the disease from getting out of hand.

With regard to the tumour-suppressor genes menin and $v h l$ the situation is more complex. To find a mutation in these genes in clinically recognized families usually means that the whole gene (coding sequence, including splice sites) has to be sequenced in at least one affected member of the family. If a mutation is identified, it has to be shown to be related to the presence of the syndrome. This means that either it has to be shown to segregate with the disease, which means that a number of affected and unaffected family members must be available for screening, or the other allele has to be shown to be destroyed also in the tumour tissue. While mutations that result in a truncated protein are generally assumed to be deleterious, 

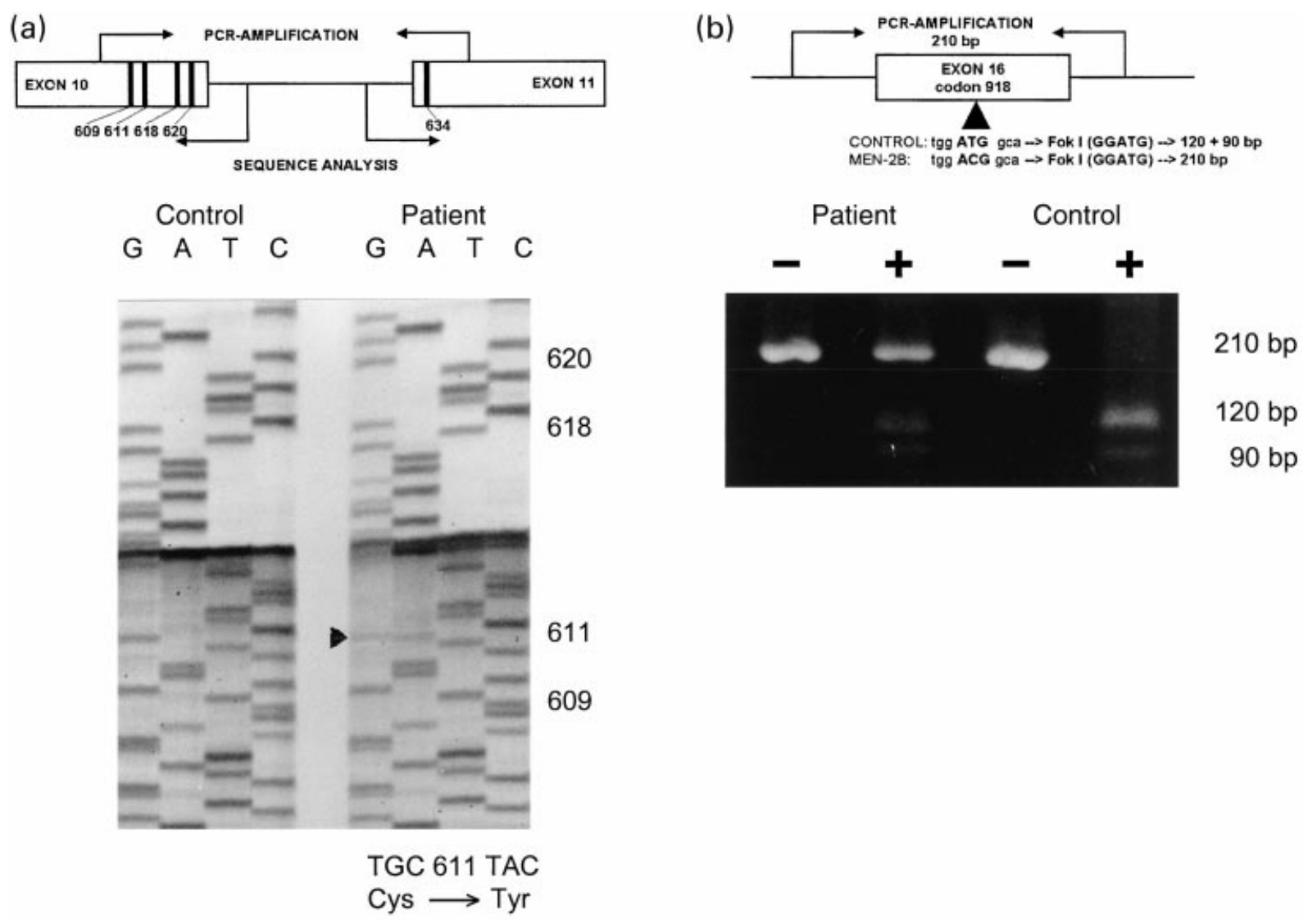

Figure 2 Schematic representation of the mutation detection procedures in possible multiple endocrine neoplasia type 2

(MEN-2) and familial medullary thyroid carcinoma (FMTC) patients. Polymerase chain reaction-amplification of a fragment containing the relevant sequences of exons 10 and 11 is followed by sequence analysis using internal primers (a). This procedure

missense mutations pose a greater problem, in this respect, because due to the lack of knowledge about the exact function of these proteins functional tests are not available at present. In the case of the menin-gene, however, the extraordinary degree of evolutionary conservation of the gene between humans and rodents [69-72] and the relative lack of amino-acid polymorphisms in the protein genome database (GDB), suggests that most, if not all amino-acid changes may be deleterious. Once a mutation has been found and shown to be responsible for the presence of the syndrome, however, looking for the presence or absence of the mutation can screen other members of the family relatively simply. In contrast to the situation in MEN-2 and FMTC, however, there are no obvious prophylactic measures that can be taken in VHL and MEN-1 carriers, and careful follow-up of these patients is the only option. In VHL the organs at which to look most specifically may be indicated on the basis of the genotypephenotype relationship described above, but in MEN-1 the apparent lack of such relationships and the intrafamilial diversity of the phenotype dictates the utmost care.

analyses the codons $609,611,618$ and 620 in exon 10 and codon 634 in exon 11, all involved in MEN-2A and FMTC. Polymerase chain reaction-amplification of exon 16, followed by treatment with the restriction enzyme FokI discriminates between carriers and non-carriers of the M918T mutation involved in MEN-2B because the mutation eliminates a FokI site (b).

\section{Germ-line mutations in apparently sporadic cases}

In all the syndromes described in this review, new hereditary cases can arise by de novo germ-line mutations. The frequency of the occurrence of germ-line mutations in apparently sporadic tumours associated with these syndromes has been reported to be in the range of 3-7\% [9-11]. In some cases, however, higher percentages have been found, e.g. germline $\mathrm{MEN}-1$ mutations in $25 \%$ of thymic carcinoids [73].

Screening for the limited number of possible mutations associated with the MEN-2 syndromes and FMTC is probably economically and practically feasible in all patients presenting with apparently sporadic medullary thyroid carcinoma or phaeochromocytoma (see Fig. 2). In the case of MEN-1 and VHL such an approach is not possible because it would in actual practice involve complete sequence analysis of at least the coding region of the genes involved. Therefore, it is necessary to apply selection criteria to these patient populations in order to increase the detection rate. For MEN-1, Roijers et al. [1] describe such a set of criteria. They have analysed, by complete sequencing of the menin-gene, $15 \mathrm{MEN}-1$ suspected patients fulfilling 
the criteria 'young ( $<35$ years) age at onset and/or multiple MEN-1 related lesions in a single organ or two distinct organs affected'. They identified mutations in nine of 15 patients $(60 \%)$, which is considerably more that the $3-7 \%$ that is found in unselected patients. Assuming that these nine mutation-positive patients represent the expected $5 \%$ of the total population presenting with MEN-1-related symptoms, it can be seen that the efficiency of this set of criteria is huge: 15 sequence analyses instead of 180 . It will be interesting to see in 5-10 years what has happened to the 165 patients that were excluded (but granted a clinical follow-up). Sequence analysis of the whole coding region of the menin-gene in selected patients (as above) is probably the best option available at present. We should, however, keep in mind that currently undefined regulatory sequences, involved in the expression of this gene may also be involved in $M E N-1$, and that splicing, despite the existence of defined splice-consensus sites, may still be found to proceed in ways that have not been identified completely.

For VHL-related tumours a similar study has not yet been reported, but it is likely that the same or a similar set of criteria will be useful in the discrimination between patients with new germ-line mutations and those with truly sporadic tumours.

\section{Somatic mutations}

Two reasons exist for searching for somatic mutations in genes associated with cancer syndromes in (truly) sporadic tumours. First, knowledge about the mechanisms of tumour development and about structure-function relationships in the proteins involved can be gained from such investigations. Second, it is sometime useful to identify these mutations because their nature may have consequences for the treatment or prognosis of the tumour. With respect to the first point, there is the observation that in sporadic medullary thyroid carcinoma somatic mutations of the MEN-2B type (methionine $918 \rightarrow$ threonine) have been found to occur much more frequently than those associated with MEN-2A [21,74,75]. This suggests that the substratespecificity of the RET tyrosine kinase activity - which is changed by the M918T mutation - plays a more crucial role in tumour formation than constitutive activation which occurs due to the MEN-2A mutations. It has indeed been suggested that in the mature thyroid gland such activation, which mimics the normal activation of the receptor, has no effect [76].

A (negative) example with regard to the second point is formed by the observation that there appears to be no difference between the behaviour of medullary thyroid carcinomas that have a somatic MEN-2B mutation and those that do not have a mutation in the ret-gene.

\section{Conclusions}

A minor proportion of sporadic endocrine tumours, estimated at approximately $6 \%$, are in fact de novo manifestations of the endocrine tumour syndromes MEN-1, MEN-2 and VHL. While it is feasible to investigate the patients with MEN-2-associated tumours for mutations in the ret-gene, because a limited number of known mutations in this proto-oncogene is associated with the MEN-2 syndromes, this is much more difficult in the case of MEN-1- and VHL-associated tumours. This is due to the fact that these two genes are tumour-suppressor genes, and any inactivating mutation in these genes may be the cause of the syndrome. A set of criteria for the selection of patients for whom mutation analysis is especially useful, such as recently described for MEN-1 [1], can significantly reduce the amount of work involved, and contributes to improved diagnostic possibilities. Future research, especially aimed at the elucidation of the function of the menin gene may further contribute to identify the mechanism that underlies the formation of tumours when this gene is inactivated. It will be especially interesting to see why this gene - besides its involvement in the MEN-1 syndrome - is also involved in tumorigenesis in some, but not all types of sporadic tumours that are also associated with MEN-1.

\section{References}

1 Roijers JFM, de Wit MJ, van der Luijt RB, Ploos van Amstel HK, Lips CJM. MEN 1 case-finding: criteria for mutation analysis in MEN 1 suspected patients. Eur $\mathcal{F}$ Clin Invest 2000;30:487-92.

2 Latif F, Tory K, Gnarra J, Yao M, Duh FM, Orcutt ML et al. Identification of the von Hippel-Lindau disease tumor suppressor gene. Science 1993;260:1317-20.

3 Mulligan LM, Kwok JB, Healey CS, Elsdon MJ, Eng C, Gardner E et al. Germ-line mutations of the RET protooncogene in multiple endocrine neoplasia type $2 \mathrm{~A}$. Nature 1993;363:458-60.

4 Donis-Keller H, Dou S, Chi D, Carlson KM, Toshima K, Lairmore TC et al. Mutations in the RET proto-oncogene are associated with MEN 2A and FMTC. Hum Mol Genet 1993;2:851-6.

5 Hofstra RM, Landsvater RM, Ceccherini I, Stulp RP, Stelwagen T, Luo Y et al. A mutation in the RET protooncogene associated with multiple endocrine neoplasia type 2B and sporadic medullary thyroid carcinoma. Nature 1994;367:375-6.

6 Eng C, Smith DP, Mulligan LM, Nagai MA, Healey CS, Ponder MA et al. Point mutation within the tyrosine kinase domain of the RET proto-oncogene in multiple endocrine neoplasia type $2 \mathrm{~B}$ and related sporadic tumours. Hum Mol Genet 1994;3:237-41.

7 Chandrasekharappa SC, Guru SC, Manickam P, Olufemi SE, Collins FS, Emmert-Buck MR et al. Positional cloning of the gene for multiple endocrine neoplasia-type 1 . Science 1997;276:404-7.

8 Lemmens I, Van de Ven WJ, Kas K, Zhang CX, Giraud S, Wautot Vet al. Identification of the multiple endocrine neoplasia type 1 (MEN1) gene. The European Consortium on MEN1. Hum Mol Genet 1997;6:1177-83.

9 Ponder B. Genetic testing for cancer risk. Science 1997;278:1050-4.

10 van der Harst E, de Krijger RR, Dinjens WN, Weeks LE, 
Bonjer HJ, Bruining HA et al. Germline mutations in the vhl gene in patients presenting with phaeochromocytomas. Int $\mathcal{F}$ Cancer 1998;77:337-40.

11 Goretzki PE, Hoppner W, Dotzenrath C, Clark OH, Simon D, Cupisti K et al. Genetic and biochemical screening for endocrine disease. World F Surg 1998;22:1202-7.

12 Krawczak M, Cooper DN. The human gene mutation database. Trends Genet 1997;13:121-2.

13 Crossey PA, Richards FM, Foster K, Green JS, Prowse A, Latif $\mathrm{F}$ et al. Identification of intragenic mutations in the von Hippel-Lindau disease tumour suppressor gene and correlation with disease phenotype. Hum Mol Genet 1994;3:1303-8.

14 Chen F, Kishida T, Yao M, Hustad T, Glavac D, Dean M et al. Germline mutations in the von Hippel-Lindau disease tumor suppressor gene: correlations with phenotype. Hum Mutat 1995;5:66-75.

15 Zbar B, Kishida T, Chen F, Schmidt L, Maher ER, Richards FM et al. Germline mutations in the Von HippelLindau disease (VHL) gene in families from North America, Europe, and Japan. Hum Mutat 1996;8:348-57.

16 Oberstrass J, Reifenberger G, Reifenberger J, Wechsler W, Collins VP. Mutation of the Von Hippel-Lindau tumour suppressor gene in capillary haemangioblastomas of the central nervous system. F Pathol 1996;179:151-6.

17 Gnarra JR, Tory K, Weng Y, Schmidt L, Wei MH, Li H et al. Mutations of the VHL tumour suppressor gene in renal carcinoma. Nat Genet 1994;7:85-90.

18 Gallou C, Joly D, Mejean A, Staroz F, Martin N, Tarlet G et al. Mutations of the VHL gene in sporadic renal cell carcinoma: definition of a risk factor for VHL patients to develop an RCC. Hum Mutat 1999;13:464-75.

19 Yang K, Lindblad P, Egevad L, Hemminki K. Novel somatic mutations in the VHL gene in Swedish archived sporadic renal cell carcinomas. Cancer Lett 1999;141:1-8.

20 Neumann HP, Berger DP, Sigmund G, Blum U, Schmidt D, Parmer RJ et al. Pheochromocytomas, multiple endocrine neoplasia type 2, and von Hippel-Lindau disease. $N$ Engl F Med 1993;329:1531-8.

21 Hofstra RM, Stelwagen T, Stulp RP, de Jong D, Hulsbeek M, Kamsteeg EJ et al. Extensive mutation scanning of RET in sporadic medullary thyroid carcinoma and of RET and VHL in sporadic pheochromocytoma reveals involvement of these genes in only a minority of cases. F Clin Endocrinol Metab 1996;81:2881-4.

22 Brauch H, Hoeppner W, Jahnig H, Wohl T, Engelhardt D, Spelsberg $\mathrm{F}$ et al. Sporadic pheochromocytomas are rarely associated with germline mutations in the vhl tumor suppressor gene or the ret protooncogene. $\mathcal{F}$ Clin Endocrinol Metab 1997;82:4101-4.

23 Bar M, Friedman E, Jakobovitz O, Leibowitz G, Lerer I, Abeliovich D et al. Sporadic phaeochromocytomas are rarely associated with germline mutations in the von Hippel-Lindau and RET genes. Clin Endocrinol (Oxf) 1997;47:707-12.

24 Brauch H, Kishida T, Glavac D, Chen F, Pausch F, Hofler H et al. Von Hippel-Lindau (VHL) disease with pheochromocytoma in the Black Forest region of Germany: evidence for a founder effect. Hum Genet 1995;95:551-6.

25 Richards FM, Schofield PN, Fleming S, Maher ER. Expression of the von Hippel-Lindau disease tumour suppressor gene during human embryogenesis. Hum Mol Genet 1996;5:639-44.

26 Schoenfeld A, Davidowitz EJ, Burk RD. A second major native von Hippel-Lindau gene product, initiated from an internal translation start site, functions as a tumor suppressor. Proc Natl Acad Sci USA 1998;95:8817-22.
27 Iliopoulos O, Ohh M, Kaelin WG Jr. pVHL19 is a biologically active product of the von Hippel-Lindau gene arising from internal translation initiation. Proc Natl Acad Sci USA 1998;95:11661-6.

28 Duan DR, Pause A, Burgess WH, Aso T, Chen DY, Garrett KP et al. Inhibition of transcription elongation by the VHL tumor suppressor protein. Science 1995;269:1402-6.

29 Garrett KP, Tan S, Bradsher JN, Lane WS, Conaway JW, Conaway RC. Molecular cloning of an essential subunit of RNA polymerase II elongation factor SIII. Proc Natl Acad Sci USA 1994;91:5237-41.

30 Aso T, Lane WS, Conaway JW, Conaway RC. Elongin (SIII): a multisubunit regulator of elongation by RNA polymerase II. Science 1995;269:1439-43.

31 Iliopoulos O, Levy AP, Jiang C, Kaelin WG Jr, Goldberg MA. Negative regulation of hypoxia-inducible genes by the von Hippel-Lindau protein. Proc Natl Acad Sci USA 1996;93:10595-9.

32 Mukhopadhyay D, Knebelmann B, Cohen HT, Ananth S, Sukhatme VP. The von Hippel-Lindau tumor suppressor gene product interacts with $\mathrm{Sp} 1$ to repress vascular endothelial growth factor promoter activity. Mol Cell Biol 1997;17:5629-39.

33 Guru SC, Goldsmith PK, Burns AL, Marx SJ, Spiegel AM, Collins FS et al. Menin, the product of the MEN1 gene, is a nuclear protein. Proc Natl Acad Sci USA 1998;95:1630-4.

34 Agarwal SK, Guru SC, Heppner C, Erdos MR, Collins RM, Park SY et al. Menin interacts with the AP1 transcription factor JunD and represses JunD-activated transcription. Cell 1999;96:143-52.

35 Agarwal SK, Kester MB, Debelenko LV, Heppner C, Emmert-Buck MR, Skarulis MC et al. Germline mutations of the MEN1 gene in familial multiple endocrine neoplasia type 1 and related states. Hum Mol Genet 1997;6:1169-75.

36 Bassett JH, Forbes SA, Pannett AA, Lloyd SE, Christie PT, Wooding $\mathrm{D}$ et al. Characterization of mutations in patients with multiple endocrine neoplasia type 1. Am f Hum Genet 1998;62:232-44.

37 Giraud S, Zhang CX, Serova-Sinilnikova O, Wautot V, -Salandre J, Buisson N et al. Germ-line mutation analysis in patients with multiple endocrine neoplasia type 1 and related disorders. Am F Hum Genet 1998;63:455-67.

38 Weitzmann MN, Woodford KJ, Usdin K. DNA secondary structures and the evolution of hypervariable tandem arrays. f Biol Chem 1997;272:9517-23.

39 Valdes N, Perez de Nanclares G, Alvarez V, Castano L, Diaz-Cadorniga F, Aller J et al. Multiple endocrine neoplasia type 1 (MEN1): clinical heterogeneity in a large family with a nonsense mutation in the MEN1 gene (Trp471Stop). Clin Endocrinol (Oxf) 1999;50:309-13.

40 Thakker RV, Bassett JH, Forbes SA, Pannett AA, Lloyd SE, Christie PT et al. Multiple endocrine neoplasia - syndromes of the twentieth century. Characterization of mutations in patients with multiple endocrine neoplasia type 1. $7 \mathrm{Clin}$ Endocrinol Metab 1998;83:2617-20.

41 Carty SE, Helm AK, Amico JA, Clarke MR, Foley TP, Watson CG et al. The variable penetrance and spectrum of manifestations of multiple endocrine neoplasia type 1. Surgery 1998;124:1106-13.

42 Burgess JR, Greenaway TM, Shepherd JJ. Expression of the MEN-1 gene in a large kindred with multiple endocrine neoplasia type 1. F Intern Med 1998;243:465-70.

43 Heppner C, Kester MB, Agarwal SK, Debelenko LV, Emmert-Buck MR, Guru SC et al. Somatic mutation of the 
MEN1 gene in parathyroid tumours. Nat Genet 1997;16:375-8.

44 Zhuang Z, Vortmeyer AO, Pack S, Huang S, Pham TA, Wang $\mathrm{C}$ et al. Somatic mutations of the MEN1 tumor suppressor gene in sporadic gastrinomas and insulinomas. Cancer Res 1997;57:4682-6.

45 Hessman O, Lindberg D, Skogseid B, Carling T, Hellman P, Rastad J et al. Mutation of the multiple endocrine neoplasia type 1 gene in nonfamilial, malignant tumors of the endocrine pancreas. Cancer Res 1998;58:377-9.

46 Debelenko LV, Brambilla E, Agarwal SK, Swalwell JI, Kester MB, Lubansky IA et al. Identification of MEN1 gene mutations in sporadic carcinoid tumors of the lung. Hum Mol Genet 1997;6:2285-90.

47 Prezant TR, Levine J, Melmed S. Molecular characterization of the men 1 tumor suppressor gene in sporadic pituitary tumors. F Clin Endocrinol Metab 1998;83:1388-91.

48 Heppner C, Reincke M, Agarwal SK, Mora P, Allolio B, Burns AL et al. MEN1 gene analysis in sporadic adrenocortical neoplasms. F Clin Endocrinol Metab 1999;84:216-19.

49 Schulte KM, Heinze M, Mengel M, Simon D, Scheuring S, Köhrer $\mathrm{K}$ et al. MEN I gene mutations in sporadic adrenal adenomas. Hum Genet. DOI 10.1007/s004399900193. 1999.

50 Schulte KM, Mengel M, Heinze M, Simon D, Scheuring S, $\mathrm{Köhrer} \mathrm{K}$ et al. Complete sequencing and messenger ribonucleic acid expression analysis of the MEN I gene in adrenal cancer. F Clin Endocrinol Metab 2000;85:441-8.

51 Takahashi M, Ritz J, Cooper GM. Activation of a novel human transforming gene, ret, by DNA rearrangement. Cell 1985;42:581-8.

52 Grieco M, Santoro M, Berlingieri MT, Melillo RM, Donghi R, Bongarzone I et al. PTC is a novel rearranged form of the ret proto-oncogene and is frequently detected in vivo in human thyroid papillary carcinomas. Cell 1990;60:557-63.

53 Eng C, Clayton D, Schuffenecker I, Lenoir G, Cote G, Gagel RF et al. The relationship between specific RET protooncogene mutations and disease phenotype in multiple endocrine neoplasia type 2 . International RET mutation consortium analysis. F Am Med Assoc 1996;276:1575-9.

54 Eng C, Mulligan LM. Mutations of the RET proto-oncogene in the multiple endocrine neoplasia type 2 syndromes, related sporadic tumours, and hirschsprung disease. Hum Mutat 1997;9:97-109.

55 Ponder BA, Smith D. The MEN II syndromes and the role of the ret proto-oncogene. Adv Cancer Res 1996;70:179-222.

56 Shirahama S, Ogura K, Takami H, Ito K, Tohsen T, Miyauchi A et al. Mutational analysis of the RET protooncogene in 71 Japanese patients with medullary thyroid carcinoma. F Hum Genet 1998;43:101-16.

57 Durbec P, Marcos-Gutierrez CV, Kilkenny C, Grigoriou M, Wartiowaara K, Suvanto $\mathrm{P}$ et al. GDNF signalling through the Ret receptor tyrosine kinase. Nature 1996;381:789-93.

58 Jing S, Wen D, Yu Y, Holst PL, Luo Y, Fang $M$ et al. GDNF-induced activation of the ret protein tyrosine kinase is mediated by GDNFR-alpha, a novel receptor for GDNF. Cell 1996;85:1113-24.

59 Trupp M, Arenas E, Fainzilber M, Nilsson AS, Sieber BA, Grigoriou $\mathrm{M}$ et al. Functional receptor for GDNF encoded by the c-ret proto-oncogene. Nature 1996;381:785-9.
60 Asai N, Iwashita T, Matsuyama M, Takahashi M. Mechanism of activation of the ret proto-oncogene by multiple endocrine neoplasia 2A mutations. Mol Cell Biol 1995;15:1613-19.

61 Borrello MG, Smith DP, Pasini B, Bongarzone I, Greco A, Lorenzo MJ et al. RET activation by germline MEN2A and MEN2B mutations. Oncogene 1995;11:2419-27.

62 Santoro M, Carlomagno F, Romano A, Bottaro DP, Dathan $\mathrm{NA}$, Grieco $\mathrm{M}$ et al. Activation of RET as a dominant transforming gene by germline mutations of MEN2A and MEN2B. Science 1995;267:381-3.

63 Takahashi M, Asai N, Iwashita T, Murakami H, Ito S. Mechanisms of development of multiple endocrine neoplasia type 2 and Hirschsprung's disease by ret mutations. Recent Results Cancer Res 1998;154:229-36.

64 Zhou S, Carraway KL, 3rd, Eck MJ, Harrison SC, Feldman RA, Mohammadi $M$ et al. Catalytic specificity of protein-tyrosine kinases is critical for selective signalling. Nature 1995;373:536-9.

65 Fearon ER. Human cancer syndromes: clues to the origin and nature of cancer. Science 1997;278:1043-50.

66 Lips CJ. Clinical management of the multiple endocrine neoplasia syndromes: results of a computerized opinion poll at the Sixth International Workshop on Multiple Endocrine Neoplasia and von Hippel-Lindau disease. $\mathcal{F}$ Intern Med 1998;243:589-94.

67 Lips CJ, Landsvater RM, Hoppener JW, Geerdink RA, Blijham G, van Veen JM et al. Clinical screening as compared with DNA analysis in families with multiple endocrine neoplasia type 2A. N Engl F Med 1994;331:828-35.

68 Lairmore TC, Frisella MM, Wells SA Jr. Genetic testing and early thyroidectomy for inherited medullary thyroid carcinoma. Ann Med 1996;28:401-6.

69 Maruyama K, Tsukada T, Hosono T, Ohkura N, Kishi M, Honda $\mathrm{M}$ et al. Structure and distribution of rat menin mRNA. Mol Cell Endocrinol 1999;156:25-33.

70 Ikeo Y, Sakurai A, Hashizume K. Characterization of the MEN1 gene product, menin, by site-specific polyclonal antibodies. Fpn f Cancer Res 1999;90:1088-95.

71 Kim YS, Burns AL, Goldsmith PK, Heppner C, Park SY, Chandrasekharappa SC et al. Stable overexpression of MEN1 suppresses tumorigenicity of RAS. Oncogene 1999;18: 5936-42.

72 Guru SC, Crabtree JS, Brown KD, Dunn KJ, Manickam P, Prasad NB et al. Isolation, genomic organization, and expression analysis of Men1, the murine homolog of the MEN1 gene. Mamm Genome 1999;10:592-6.

73 Teh BT, Zedenius J, Kytola S, Skogseid B, Trotter J, Choplin $\mathrm{H}$ et al. Thymic carcinoids in multiple endocrine neoplasia type 1. Ann Surg 1998;228:99-105.

74 Komminoth P, Kunz EK, Matias-Guiu X, Hiort O, Christiansen G, Colomer A et al. Analysis of RET protooncogene point mutations distinguishes heritable from nonheritable medullary thyroid carcinomas. Cancer 1995;76:479-89.

75 Eng C, Mulligan LM, Smith DP, Healey CS, Frilling A, Raue $\mathrm{F}$ et al. Mutation of the RET protooncogene in sporadic medullary thyroid carcinoma. Genes Chromosomes Cancer 1995;12:209-12.

76 Mak YF, Ponder BA. RET oncogene. Curr Opin Genet Dev 1996;6:82-6. 